ARTICLE | Philosophy and Critique

\title{
Violence in Alain Badiou's Emancipatory Politics
}

Regletto Aldrich D. Imbong

\begin{abstract}
This paper discusses the significance of violence in Alain Badiou's concept of emancipatory politics. In literatures that affirm revolutionary ideas, violence is often justified as a legitimate form of resistance. This for example was explained by Fanon and Marx. There is a need to carefully study violence as a modality of resistance for two reasons. First, the discourse on violence as a modality of resistance must position itself away from the defensive side of the political spectrum. Its revolutionary and liberating possibility has been undermined as it is assumed, rather than argued, by dominant discourse as fundamentally unacceptable. A discourse on violence which is positive in nature must be articulated not only for the purpose of defending and rescuing such a revolutionary means from all the vilifying campaigns of contemporary reaction, but most of all to posit violence, borrowing from Badiou's emancipatory politics, as a consequence of a positive or affirmative revolutionary creative act. Second, any affirmation of violence as a modality of resistance must not be confused with an absolution from political responsibility. Violence needs to recognize its own limits so as not to commit the grave historical error with finally identifying itself with terror and defeating its own emancipatory goals. Consciously minding violence's restrictions renders such a modality of resistance not only effective but above all a powerful condition for the construction of the New.
\end{abstract}

Keywords: Event, violence, emancipatory politics, state

(C) 2016 Regletto Aldrich D. Imbong

http://www.kritike.org/journal/issue_19/imbong_december2016.pdf

ISSN 1908-7330 
7 his paper discusses the significance of violence ${ }^{1}$ in Alain Badiou's concept of emancipatory politics. In literatures that affirm revolutionary ideas, violence is often justified as a legitimate form of resistance. This, for example, was explained by Fanon when he stressed the role of revolutionary violence in the process of decolonization. ${ }^{2}$ Even Marx recognized the role of violence in the eventual seizure of political power by the proletariat from the bourgeoisie, albeit not suggesting the necessity of such violence for society to forward towards communism. ${ }^{3}$ In any case, there is a need to carefully study violence as a modality of resistance for two reasons.

First, the discourse on violence as a modality of resistance must position itself away from the defensive side of the political spectrum. Its revolutionary and liberating possibility has been undermined as it is assumed, rather than argued, by dominant discourses as fundamentally unacceptable. ${ }^{4}$ The campaign to render violence as an unacceptable form of resistance has painted a negative image of political violence oftentimes discredited as either irrational outbursts of the impulses of the weak, or if not mere banditry. ${ }^{5} \mathrm{~A}$ discourse on violence which is positive in nature must be

${ }^{1}$ What I mean by violence is the political violence that is contemporaneous with a massive popular resistance, oftentimes in a form of revolution or armed uprising. This violence is not just any form of physical harm against others, as this violence, according to Arendt, quoting Engels, systematically uses implements, i.e., arrows, spears, guns, canons, etc. See Hannah Arendt, On Violence (New York: Harcourt Brace Jovanovich, 1970), 4, 42, 46. Further, this violence is conditioned by what Badiou calls as an Event. Hence, the violence that I am referring to excludes criminal violence like murder, genocide, and most especially, terroristic actions of fundamentalist groups which bear no relation to the New embodied by every Event.

2 Priyamvada Gopal, "Concerning Maoism: Fanon, Revolutionary Violence, and Postcolonial India," in The South Atlantic Quarterly, 112:1 (2013), 117-118.

${ }^{3}$ Arendt explained that "Marx was aware of the role of violence in history, but this role was to him secondary; not violence but the contradictions inherent in the old society brought about its end. The emergence of a new society was preceded, but not caused, by violent outbreaks, which he likened to the labor pangs that precede, but of course do not cause, the event of organic birth." Arendt, On Violence, 11.

San Juan clarified the dialectics between violent and peaceful means within Marxist discourse. He explained that " $[w]$ here the state bureaucracy supporting the bourgeoisie and the standing army do not dominate the state apparatus completely (a rare case) or has been weakened, as in the case of monarchy and the Russian bourgeoisie at the time of the Bolshevik Revolution in 1917, the working class might attain their goal of class liberation by peaceful means; but in most cases, 'the lever of the revolution will have to be force' harnessed by the masses unified by class consciousness and popular solidarity." See Epifanio San Juan Jr., "Nationalism, the Postcolonial State, and Violence," in Pingkian: Journal for Emancipatory and Anti-Imperialist Education, 4:1 (2015), 30.

4 Priyamvada Gopal, “Concerning Maoism: Fanon, Revolutionary Violence, and Postcolonial India," 116.

${ }^{5}$ Banditry was how Emilio Aguinaldo described the resistance movement after the Pact of Biak-na-Bato. See Renato Constantino, The Philippines: A Past Revisited, vol. 1 (Quezon City: The Foundation for Nationalist Studies, 1975), 198.

(c) 2016 Regletto Aldrich D. Imbong

http://www.kritike.org/journal/issue 19/imbong december2016.pdf

ISSN 1908-7330 
articulated not only for the purpose of defending and rescuing such a revolutionary means from all the vilifying campaigns of contemporary reaction, but most of all to posit violence, borrowing from Badiou, as a positive or affirmative revolutionary proposition ${ }^{6}$ feared by none except the oppressors and exploiters of history hostile to the construction of equality.

Second, any affirmation of violence as a modality of resistance must not be confused with an absolution from political responsibility. Violence needs to recognize its own limits so as not to commit the grave historical error with finally identifying itself with terror and defeating its own emancipatory goals. Tortures, concentration camps and purging campaigns are among the many living testaments to this great temptation. With these reasons presented, I shall argue that violence as a modality of resistance is dialectical: it is a category determined both by what it is and what it is not. Consciously minding violence's dialecticity renders such a modality of resistance not only effective but above all a powerful condition for the construction of the New.

\section{The Illegal Subject of the Event}

A favorable discourse on violence as a modality of resistance can be achieved through a brief discussion of Alain Badiou's notion of emancipatory politics. It is invariably the case that every genuine political sequence is one which affirms the thinking and construction of the New. This political sequence builds and nurtures itself under the principle of dialectics: progression over reaction, the New over the old. Political sequences of the past, from the slave rebellions up to the most recent uprisings testify to this projection of a collective body organizing a new possibility irreducible to the terms and logic of the old and the given. Only a politics which affirms the New, rather than the desperate maneuvering to salvage and project with a "human face" the old, 7 deserves the name politics of emancipation. The latter is not a mere representation of the old or given situation since emancipatory

\footnotetext{
${ }^{6}$ Badiou however described the Event, not violence, as an affirmative dialectics. I would borrow such a terminology to describe violence. Alain Badiou, "Affirmative Dialectics: from Logic to Anthropology," in The International Journal of Badiou Studies, 2:1 (2013).

7 This is what, from the language of Slavoj Žižek, cultural capitalism has been successfully maneuvering. Starbucks, Nike, and many other capitalist enterprises have humanized its project by incorporating into its business philanthropic practices that allegedly gives aid to the impoverished of the world. In this way, it presents capitalism as less brutal if not the only viable solution to poverty. See a brief elaboration of Žižek's critique on the subject, Peter Suechting, "Global Capitalism with a Human Face?" in AC Voice (2 December 2012), <https://acvoice.com/2012/12/02/global-capitalism-with-a-human-face/> , 5 December 2015.
}

(c) 2016 Regletto Aldrich D. Imbong

http://www.kritike.org/journal/issue 19/imbong december2016.pdf

ISSN 1908-7330

$(c c))$ BY-NC-ND 
politics "draws itself from the void that an event brings forth as the latent inconsistency of the given world." 8

In Badiouian ontology, an Event is a moment of the opening of a new possibility within a given situation. ${ }^{9}$ Badiou explained that it "is something that brings to light a possibility that was invisible or even unthinkable .... It indicates that ... a possibility exists that has been ignored." 10 The Event, far from being a normal continuity of any logical routines (in science, art, politics, or love), "interrupts the law, the structure of the situation ..."11 The Event is a moment which both defies given normality and stability-since all Events are abnormal, and that there are no natural or neutral Events ${ }^{12}$-and serves as a harbinger of a possibility not anymore in the order of the old but that of the New.

The happening of an Event is a moment which is affirmative in its very nature. As opposed to Hegelian or even Marxist dialectics which prioritizes the category of the negative over the affirmative, the Event, despite being a point of defiance, is primarily an affirmation, i.e., the affirmation of the New opened up through the happening of an Event. We may take as an example the 1896 Philippine Revolution. Far from being a mere negative reaction against the excesses of Spanish Colonialism, it was above all the affirmation of "nationhood:" a category absent from the consciousness and language of pre-Revolutionary Filipinos. ${ }^{13}$ The new subjectivity - through the formal organization of the revolutionary $K K K$-tempered through time, thinks and organizes a new possibility-i.e., nationhood-which is far too radical to be envisioned from a colonial perspective. Even the intellectuals ${ }^{14}$ of that time, well-versed of the leading political philosophies, found it hard, if not impossible to think such a possibility - thereby ultimately surrendering to reformism-yet this paradox is one peculiar character of an Event: the thinking of the impossible. ${ }^{15}$ In this context, Constantino precisely described

8 Alain Badiou, Conditions, trans. by Steven Corcoran (New York: Continuum, 2008),

${ }^{9}$ For a discussion on Badiou's concept of the Event, see Alain Badiou, Being and Event, trans. by Oliver Feltham (New York: Continuum, 2005), 173-183.

10 Alain Badiou, Philosophy and the Event, trans. by Louise Burchill (Massachusetts: Polity Press, 2013), 9.

11 Badiou, "Affirmative Dialectics: From Logic to Anthropology," 3.

12 Badiou, Being and Event, 175, 178.

13 I mean the "natives" who were then properly called as Indios. Of course, the term Filipinos was reserved for the Insulares but I want to use it being the proper term for a nation under revolt.

${ }^{14}$ I refer to the reformists whose actions and programs fall under the "preservation of being."

15 "For Badiou, truths exempt themselves from what there is: they erupt in the form of what he names an "event" and initiate the new and the formerly impossible." See Ronjaunee Chatterjee, "Alain Badiou in Southern California: A Politics of the Impossible," in Los Angeles

(C) 2016 Regletto Aldrich D. Imbong http://www.kritike.org/journal/issue 19/imbong december2016.pdf ISSN 1908-7330 


\section{BADIOU AND VIOLENCE}

the Revolution as an affirmation of an Event when he argued that "[ $t$ ]he nation was born of the Revolution as much as the Revolution was the expression of the nation being born." ${ }^{16}$ Hence, in relation to the 1896 Revolution, the Cry of Pugadlawin was an Event.

For the Event to be, i.e., for a singular happening not to be lost in the myriad of the usual, ordinary, and routinary happenings, the Event must be affirmed. ${ }^{17}$ Without such second affirmation, the Event would just be lost in the infinity of what might be and "nothing would have taken place, but place." 18 From the contingency that it is, the Event is sealed and pursued thereby organizing a new way of living. Love is one concrete example for this affirmation of an Event. Being one of Badiou's "truth procedures" (the others being science, art and of course politics), love is always conditioned by an Event-the event-encounter of the Two. But this contingency-a happening purely set by chance-has to be sealed through an affirmation, i.e., a declaration of love: I love you. Badiou explained that "[o]nce the encounter is determined in the declaration, whatever form this may take, the amorous experience in the strict sense begins: that of a world 'existed' by two." 19 A new subjectivity of the Two finally begins. And with this new subjectivity conditioned by love, the paramours invent "a different way of lasting life." 20

The affirmation of an Event produces the sudden emergence of a subject. This sudden emergence reveals the Event's dialecticity: it is not pure affirmation but also a negation. Badiou acknowledged that the Event produces sequences that

are different forms of negation-struggle, revolt, a new possibility to be against something, destruction of some part of the law, and so on-but these forms of negation are consequences of the birth of the new subjectivity, and not the other way around; it is not the new subjectivity that is a consequence of the negation..$^{21}$

Review of Books (6 February 2014), <https://lareviewofbooks.org/article/alain-badiou-southerncalifornia-politics-impossible/\#! $>$, 5 December 2015.

${ }^{16}$ Renato Constantino, The Philippines: A Past Revisited, 145.

${ }_{17}$ Badiou explained that "[a]n event is, in general, almost nothing: it appears at the same time as it disappears; it's not immediately evident that it has any future at all, and it can't at first be deciphered as regards its consequences." Badiou, Philosophy and the Event, 42.

${ }^{18}$ This is originally from the poet Mallarme adopted by Badiou in describing situations unaffected by an Event and its procedure.

${ }^{19}$ Badiou, Philosophy and the Event, 43.

${ }^{20}$ Badiou, In Praise of Love, trans. by Peter Bush (Paris: Flammarion, 2012), 33.

${ }^{21}$ Badiou, "Affirmative Dialectics: From Logic to Anthropology," 4.

(c) 2016 Regletto Aldrich D. Imbong

http://www.kritike.org/journal/issue 19/imbong december2016.pdf

ISSN 1908-7330

(c) $\mathrm{BY}-\mathrm{NC}-\mathrm{ND}$ 
In politics, this new subjectivity affirming the Event is the collective, the mass of militants faithful to the procedures dictated by an emancipatory politics. But the sudden emergence of a collective subject is not so much a natural consequence of the given situation as an illegal decision. Even the Event is not natural since what is natural is mere Being. And it should be noted that Being prohibits the Event. ${ }^{22}$ Meillassoux explained that "an event is an exception to being not insofar as it would not be a multiple, but insofar as its multiplicity is ontologically forbidden ..." ${ }^{23}$ As against the Event, Being is in the order of the natural: it is the active preservation of normality and stability. From a political perspective, this preservation of being is a masterpiece and a necessary condition of the State: the state is not founded upon the social bond, which it would express, but rather upon un-binding, which it prohibits. ${ }^{24}$ Consequently, Being's prohibition of the Event demands a radical if not illegal ${ }^{25}$ choice necessary for the procedure of the New. This choice is the intervention of a new subjectivity faithful to the consequences of the Event. The new subjectivity organizes in the old situation a new sequence of thought and existence, a possibility which could not have been if the Event had not happened and pursued faithfully by the collective.26 The Revolutionary $K K K, 27$ the new subjectivity that intervened between the Event and the construction of the New (i.e., nationhood), is the living trace of the vanished Event. Thanks to the Event that was, the Revolution has incorporated within the old situation the possibility of an impossibility, thereby pushing Philippine society towards a new stage of development.

\footnotetext{
22 Badiou, Being and Event, 184.

${ }^{23}$ Quentin Meillassoux, "History and Event in Alain Badiou," trans. by Thomas Nail in Parrhesia, 12 (2011), 2.

${ }^{24}$ Badiou, Being and Event, 109.

25 "The nomination is essentially illegal in that it cannot conform to any law of representation ... But since the intervention extracts the supernumerary signifier from the void bordered on by the site, the state law is interrupted. The choice operated by the intervention is a non-choice to the state, and thus for the situation, because no existent rule can specify the unpresented term which is thereby chosen as name of the pure evental 'there is.'" Ibid., 205.

${ }^{26}$ Badiou explained this thoroughly using the case of Christianity. He said that "[i]n the case of Christianity, they affirm the resurrection. After that there are a lot of practical and symbolic consequences in all situations. But what is interesting in the example of Paul is that the very beginning of something new is always something like a pure affirmation of the new possibility as such. There is a resurrection; you have to affirm that! And when you affirm the resurrection, and you recognize that sort of affirmation-because affirmation is with others and in the direction of others-you create something absolutely new, not in the form of a negation of what exists, but in the form of newness inside what exists. And so, there is no longer negation on the one hand and affirmation on the other. There is rather affirmation and division, or the creation that grounds the independence of new subjects from within the situation of the old." Badiou, "Affirmative Dialectics: From Logic to Anthropology," 5.

${ }^{27}$ Kataastaasang, Kagalanggalangang Katipunan ng mga Anak ng Bayan, or KKK, is the revolutionary group that toppled Spanish Colonialism in the Philippines.
}

(C) 2016 Regletto Aldrich D. Imbong

http://www.kritike.org/journal/issue 19/imbong december2016.pdf ISSN 1908-7330 


\section{Subjective Violence against the State}

The emergence of the political subject-i.e., the collective-reveals the dialecticity of an Evental rupture. Not only is the Event anymore an affirmation of the New, the Event, the immanent possibility of change in the structure of reality, now poses, through a collective subject, a negative character not to what is faithfully affirmed but to that which persistently if not ferociously prohibits the Event: The State.

Earlier it was mentioned how the Event is ontologically forbidden by Being-or politically, by the State. Tracing the development of the latter, it can be presumed that it is "a product of the irreconcilability of class antagonisms." 28 As these antagonistic struggles sharpen, the State enters into the field of contradiction not actually to reconcile-although reconciliation is one effective means to conceal the ever-sharpening social contradictions-but to suppress and tame the weaker force. In the past, the State reveals itself as the dominant force (e.g., Spanish Colonial Period). Without any pretense and mediation, the Spanish colonial masters unleashed brutality against the Indios in order to exact forced labor, tributes, and taxes among others. The absence of any mediating agent in the commission of violence is peculiar to any colonial space. ${ }^{29}$ Today - what many conveniently describe as postcolonial era-the State identifies itself with (e.g., bourgeois representative government) the dominant force. ${ }^{30}$ In any case, the statement "the State is the state of the ruling class" 31 holds true. This analysis reveals the deceptive character of any social contract theory as the latter, built on lies and fiction, 32 glosses over the contradiction of classes and their respective relations toward the State and private property. Even Locke, although entertaining the possibility of a people's rebellion, still worked within the conception of a political organization dependent on a State that primarily defends property. ${ }^{33}$

\footnotetext{
${ }^{28}$ Vladimir Lenin, V.I. Lenin: Collected Works, trans. by Stepan Apresyan and Jim Riordan (Moscow: Progress Publishers, 1917), 390.

${ }^{29}$ See for example the elaboration of Reyes in Alvaro Reyes, "On Fanon's Manichean Delirium," in The Black Scholar: Journal of Black Studies and Research, 42:3-4 (2012), 15.

${ }^{30}$ Guerrero explained that "[w]ith US imperialism enlarging its interests at the expense of the broad masses of the people, the colonial bureaucrats have become bureaucrat capitalists. They are capitalists by keeping the entire government as a large private enterprise from which they draw enormous private profits. They act as the local managers of the US monopolies. They serve the comprador big bourgeoisie and the landlord class which are their internal material basis." See Amado Guerrero, Philippine Society and Revolution (Manila: Aklat ng Bayan, 2006), 114.

${ }^{31}$ As Badiou described the fundamental conception of Marxism of the State, "the State 'is the State of the ruling class.'" Badiou, Being and Event, 105.

${ }^{3}$ San Juan, "Nationalism, the Postcolonial State, and Violence," 32.

${ }^{33}$ John Locke, "The Second Treatise of Civil Government," in The Great Political Theories, vol. 1, ed. by Michael Curtis (New York: Harper Perennial Modern Classics, 2008), 375.
}

(c) 2016 Regletto Aldrich D. Imbong

http://www.kritike.org/journal/issue 19/imbong december2016.pdf

ISSN 1908-7330

(c) BY-NC-ND 
This union of the state and the ruling class necessitates a structure of violent contradictions. Although Lenin in this case specifically referred to the bourgeois state, it could also be argued that this violent structure of the state is true not only of the bourgeois state but even in previous political organizations. Thus, even during the Spanish colonial and feudal period, violence was already resorted to by the friars who have absolute control of the frailocratic machinery. ${ }^{34}$

Weber has a point when he said that only the State has the monopoly of the use of legitimate violence or force. Quoting Trotsky, Weber reiterated that "[e]very state is based on force." 35 However, the context of this monopoly is within the State's subtle paranoia: preservation from gradual disintegration as a result of sharpened contradictions. As Weber pointed out, "[i]f the state is to survive, those who are ruled over must always acquiesce in the authority that is claimed by the rulers of the day." 36 The state's alleged guardianship of the sacred social bond is nothing more but the inverted expression of its fear against social disintegration and the gradual loss of the means of production from the hands of a private few. In other words, without the employment of (a means called) violence, the State is in danger of anarchy. ${ }^{37}$ This violence of the state, otherwise charged as state terror, ${ }^{38}$ is violence pure and simple.

The possibility of violence can only take place within the intersection of the collective subject and the State. Both intersect since they are guided by opposed maxims and trajectories: one aims at progression, the other reaction; one for equality, the other for unbridled liberty. Badiou explained that the maxim of the Western democratic world is liberty, i.e., the freedom to accumulate properties, capital, and wealth. ${ }^{39}$ On the other hand, an

${ }^{34}$ Constantino, The Philippines: A Past Revisited, 72, 80, 148.

${ }^{35}$ Max Weber, The Vocation Lectures: Science as a Vocation, Politics as a Vocation, trans. by Rodney Livingstone, ed. by David Owen and Tracy Strong (Indianapolis: Hackett Publishing Company, 2004), 33.

${ }^{36}$ Ibid., 34.

${ }^{37}$ Ibid., 33.

${ }^{38}$ See for example Raymond Sebastian, "Lumads open 'identity museum' in Baclaran," in CBCP News (20 November 2015), <http://www.cbcpnews.com/cbcpnews/?p=68121>, 22 December 2015; Jose Maria Sison, “On the ceaseless state terrorism against the Filipino people since 1972," in International League of Peoples' Struggle (21 September 2015), $<$ http://www.ilps.info/index.php/en/statements/1898-on-the-ceaseless-state-terrorism-againstthe-filipino-people-since-1972>, 22 December 2015; and Carol Pagaduan-Araullo, "Lumad killings and counterinsurgency," in Bulatlat: Journalism for the People (21 September 2015), $<$ http://bulatlat.com/main/2015/09/21/lumad-killings-and-counterinsurgency/>, 22 December 2015.

${ }^{39}$ As Badiou puts it in his hypertranslation of Plato's Republic, "'freedom' reduced to the compulsory gratification of personal desires through the objects available on the market. The norm is in fact normless 'freedom,' meaning sheer animality." See Alain Badiou, Plato's Republic, trans. by Susan Spitzer (New York: Columbia University Press, 2012).

(C) 2016 Regletto Aldrich D. Imbong

http://www.kritike.org/journal/issue 19/imbong december2016.pdf ISSN 1908-7330 
emancipatory politics maintains equality as its axiom. ${ }^{40}$ Along with many egalitarian thinkers, Rousseau and Badiou affirmed that the collective, guided by the general will, recognizes that equality is far more important than liberty. ${ }^{41}$ In Marxist discourse, this is the communist principle.

The upward movement of political subjects is immediately prohibited by the State who is hell bent to preserve the nature of things. Today, as well as in the past, this nature of things not only includes the cultural and spiritual traits of the given situation but most of all the economic and property relations among classes. For over five centuries of relentless preservation against capitalist disintegration, the bourgeoisie has more than ever learned to be ruthless and violent just to maintain and never rock the state of things. This is true today as it was in the past. ${ }^{42}$ Despite the "democratization" of the bourgeois political space-a challenge posed against all espousing revolutionary ideas-violence has been an important character trait of the bourgeois ruler and state. Perfectly aware of this truth, Žižek confirmed the symbiotic relationship between violence and the state when he noted that "[t]he notion of objective violence needs to be thoroughly historicised: it took on a new shape with capitalism." ${ }^{43}$ Mincing no words, we can conclude that the State is "the political institution with centralized authority and monopoly of coercive agencies coeval with the rise of global capitalism ..." 44

In this way, the notion of State ceases to be an empty signifier when it is effectively historicised and placed vis-a-vis capitalist accumulation and expansion. The state cannot be anything more than the active defender of

This cherished liberty has however resulted to monstrous inequalities both within and outside capitalist countries. See Alain Badiou, Philosophy for Militants, trans. by Bruno Bosteels (New York: Verso, 2012), 31. As a matter of fact, this inequality is confirmed by the Oxfam report that " $[\mathrm{t}]$ he combined wealth of the richest 1 percent will overtake that of the other 99 percent ..." See "Richest 1\% will own more than all the rest by 2016," in Oxfam International (19 January 2015), $<$ https://www.oxfam.org/en/pressroom/pressreleases/2015-01-19/richest-1-will-own-more-allrest-2016>, 7 January 2016.

${ }^{40}$ See Alain Badiou, Metapolitics, trans. by Jason Barker (New York: Verso, 2011), 99.

${ }^{41}$ See the following: Jean-Jacques Rousseau, Discourse on the Political Economy and the Social Contract, trans. by Christopher Betts (New York: Oxford University Press, 1994), 86-87; Badiou, Philosophy for Militants, 31; and Badiou, Metapolitics, 97.

42 We may refer to the International People's Tribunal on Crimes Against the Filipino People convened in Washington which confirmed that big foreign mining industries are the interests behind the displacement and killings of the Lumad in Mindanao. See Vanessa Lucas and Azadeh Shahshahani, "The Philippine People Are Under Attack from Washington - and

Their Own Government," in The World Post (3 December 2016), $<$ http://www.huffingtonpost.com/azadeh-shahshahani/the-philippine-peopleare b 8714174.html>, 4 January 2016.

${ }^{43}$ Slavoj Žižek, Violence: Six Sideways Reflections (Pine Street: Profile Books, 2009), 10.

${ }^{44}$ Epifanio San Juan Jr., "Nationalism, the Postcolonial State, and Violence," 24.

(c) 2016 Regletto Aldrich D. Imbong

http://www.kritike.org/journal/issue 19/imbong december2016.pdf

ISSN 1908-7330

(c) $\mathrm{BY}-\mathrm{NC}-\mathrm{ND}$ 
Capital ${ }^{45}$ whose existence, as what Marx long before clarified, necessitates the exploitation of the workers and the plunder of resources. Even without being obviously violent, the State-Capital combine has been silently violent against those who toil in order to survive. This is an example of violence, pure and simple - a violence alien to any Event.

\section{Towards an Affirmative Discourse of Violence}

Violence, pure and simple, has nothing to do with change. The violent blow of a man to a woman doesn't change anything, especially the subordinate role of the woman against the man. This kind of violence effectively preserves the natural structure of the given, i.e., subordination, patriarchy, misogyny, etc. In the political level, state violence does not and will never change the structure of society. The Martial Law years as well as the killing of the Lumad are proofs to this proposition. In both cases and in all cases of state terror, a state's ferocity is unleashed against helpless, recalcitrant people, with the aim of silencing the latter. But then again, in situations instigated by violence pure and simple, change is never achieved, at least in two respects. First, on the subjective level, the desired change evident on the aim of "silencing" the subversives only serve to further fuel the rage of a terrorized people, thereby defying silence itself. Notice how the Lumad journeyed the archipelago, from the island of Mindanao up to the Capital (which they famously called the Manilakbayan) to denounce all forms of state terrorism against their own. ${ }^{46}$ State terror never silenced them. In other words, they were never changed and converted to become silent and unquestioning subjects. This is also true in relation to the terror unleashed during the Martial Law years which only created a discontented and enraged people. Second, on the objective level, nothing of the material reality transformed. Further entrenched through state terror is an elite politics of oligarchs, colluding with foreign powers, and plundering the resources of the nation, both natural and human. In both historical instances, the same structure remains. Hence, violence, pure and simple, does not include change among its elements in the same way as oxygen does not include fire.

45 Interestingly, the same Oxfam report cited earlier revealed that finance and pharmaceutical interests spend $\$ 550$ million and $\$ 500$ million respectively for lobbying policy makers in Brussels and Washington, and the finance interests provided \$571 million for campaign contributions. We could not help but speculate how the State (of course run by the beneficiaries of these interests) reciprocates the generosity of these big businesses. See "Richest $1 \%$ will own more than all the rest by 2016," in Oxfam International.

${ }^{46}$ See for example Voltaire Tupaz, “\#Manilakbayan: UP Diliman welcomes 700 Lumad from Mindanao," in Rappler (26 October 2015), <http://www.rappler.com/move-ph/110730manilakbayan-up-diliman-welcomes-lumad-mindanao $>, 22$ December 2015.

(c) 2016 Regletto Aldrich D. Imbong

http://www.kritike.org/journal/issue 19/imbong december2016.pdf

ISSN 1908-7330

(cc) BY-NC-ND 
But the converse of the first proposition is not true; i.e., change has nothing to do with violence. Here, the rules of logic fail. Change has something to do with violence. Change, is an Event which ruptures: ${ }^{47}$ the situation includes, among its elements, violence in the same way as fire includes oxygen. However, this does not suggest a structural relationship of the terms as similar to the structure of dialectics: thesis and antithesis (and of course the synthesis). In dialectics, the terms are mutually exclusive: exclusive as they are contradictions, mutual as their contradictions are necessary. One is not subordinated by the other, in fact the two dictates the unity of being, or if we use Badiou's language, there is the structural precedence of the Two over the One. ${ }^{48}$ But in the category of change (which of course is dialectical), violence is a subordinate. Change is a regime not of violence but of dialectics: the contradiction and gradual abolition of classes. And under the command of this dialectics is a contingent force called violence. In practical terms, dialectics readily arms itself without necessarily harming the other. ${ }^{49}$ The political subjects under an emancipatory politics remain gentle while maintaining militant vigilance. Like Mao, the militant subjects openly admit that "[f]irst of all, we do not like war, and second of all, we do not fear it." ${ }^{50}$ Emancipatory politics in this regard is like fire giving a comforting warmth without necessarily burning the comforted. Hence, while change is necessary, violence is not. Violence's contingency takes two forms. On the one hand, it is contingent as it may not be the only form of struggle. In revolutionary sequences, the armed struggle does not have to be the only viable path for the attainment of revolutionary change, for if this is so, support (be it financial, moral, political or logistical) for such a cause would immediately be unhelpful to it as direct participation (in the armed struggle) is the sole demand. This is a reckless strategy that immediately rules out the possibility of rallying the broadest number of people towards a revolution.

\footnotetext{
${ }^{47}$ McGowan explained that Badiou as well as Žižek believed that "rupture must have a violent quality to it." See Todd McGowan, "Subject of the Event, Subject of the Act: The Difference Between Badiou's and Žižek's Systems of Philosophy," in Subjectivity, 3:1 (2010), 2122. vol. 3, no. 1 (2010): 21-22.

48 See Badiou, Plato's Republic, 139.

${ }^{49}$ Unreported by mainstream media, the New People's Army (NPA) cleverly raided a detachment of the $7^{\text {th }}$ Regional Mobile Group-Combat Support Company in Barangay Rizal, Batuan, Bohol, and seized 84 firearms without firing a single shot, last 11 June 1999. See "New People's Army (NPA) launches a series of tactical offensive against Estrada's reactionary armed forces," in People's March: Voice of the Indian Revolution (September-October 1999), $<$ http://www.bannedthought.net/India/PeoplesMarch/PM1999-2006/archives/1999/sep-

oct 99/npa.htm $>, 22$ December 2015. As a consequence to this non-violent raid, the PNP's anger was directed against its own personnel as it fired 37 policemen for neglect of duty. See. Sol Jose Vanzi, "Bohol Cops in NPA Raid Fired, Charged for Neglect," in Philippine Headline News Online (13 June 1999), <http://www.newsflash.org/1999/06/ht/ht000800.htm>, 22 December 2015.

${ }^{50}$ As quoted in Badiou, Plato's Republic, 123.
}

(c) 2016 Regletto Aldrich D. Imbong

http://www.kritike.org/journal/issue 19/imbong december2016.pdf

ISSN 1908-7330

(c) BY-NC-ND 
This stupidity was never the practice of the Revolutionary KKK. For if it had been a strict policy then, Melchora Aquino, despite of her old age, would have been forced and dragged towards holding up arms. But she was not. However, she was an element of change, i.e., of the revolution. But there wasn't anything violent in her being a part of change. Certainly, she contributed and in fact supported the revolutionary cause without necessarily becoming physically violent. Did she contribute to societal change? Of course, she did. She and her likes were a contribution to the revolution (and never to reformism) because, and this is now my presumption, genuine change is such a multiplicity which, first, ruptures the law and logic of the situation by way of a collective struggle; second, constructs an egalitarian/communist political space; and third, unhesitatingly includes among its elements violence, without however implying the necessary deployment of the latter.

The proposition raised above would be more relevant when viewed within the context of political struggles in contemporary democratic states. It is of course an accepted fact that today's political configuration is one which is mainly dictated by bourgeois democracy, something which Badiou described as democratic materialism. ${ }^{51}$ And the power and influence of this ideology has seeped through almost all aspects of human existence, including culture, education, and most of all politics. The democratization of the political space, thanks to the proponents of liberal philosophies like Locke, has allowed the regime of representations. Not only that, bourgeois democracy has even been hailed (of course by the liberals) as the best possible rule, as it has become, unlike tyranny and oligarchy, the Rule by Nobody. ${ }^{52}$ A reference to this kind of rule has been the convenient description or defense of the ruling class. The latter has effectively camouflaged itself within modern democracy's flexible dynamics of bureaus thereby blurring, first of all, responsibility and consequently effective political resistance. This political scenario and the consciousness that goes with it pose a difficult challenge against any form of emancipatory politics, especially the naive type which only praises a purely armed political intervention.

With this political situation entrenched, a popular movement committed to an Event could not just rule out forms of struggle that are within the rules and logic of democratic systems. Gopal raised "the larger question

${ }^{51}$ Alain Badiou, Logics of Worlds: Being and Event II, trans. by Alberto Toscano (New York: Continuum, 2009), 1-4.

52 Tracing the development of forms of government, Arendt charged that "[t]oday we ought to add the latest and perhaps the most formidable form of such dominion: bureaucracy or the rule of such an intricate system of bureaus in which no men, neither one or the best, neither the few nor the many, can be held responsible, and which could be properly called rule by Nobody." Arendt, Violence, 36.

(c) 2016 Regletto Aldrich D. Imbong

http://www.kritike.org/journal/issue 19/imbong december2016.pdf ISSN 1908-7330 
of how radical change ... might be achieved in the context of a capitalism that works through the appropriation of democratic structures ..."53 While maintaining political independence and firmness of principles, a politics of emancipation's strategy must be as flexible as possible. Against Badiou who is quite pessimistic on parliamentary interventions, ${ }^{54} \mathrm{I}$ argue that the latter, in the conduct of an emancipatory politics, plays a significant role although not as much as armed forms of struggle do. This does not suggest, however, a purely parliamentarian struggle, for if such a struggle exists, i.e., one which does not include among its terms/elements, violence, it is not in the order of the Event and therefore fails to pass the requirement of a politics of emancipation. Furthermore, this purely parliamentarian resistance defeats the idea of an emancipatory politics as it is already accommodated inside the State rather than autonomously existing outside of it. To be inside the State is to be incorporated within the State machinery thereby betraying the Event since the State is, again, in the order of Being and not of the Event. However, building and maintaining a political strength primarily and independently from the outside while effectively penetrating the inside establishes the autonomy of a movement which limits if not rules out the possibility of a betrayal to the Event. As Badiou insisted, "we will have to create something that will be face to face with the State-not inside the State, but face to face with it." 55 From the perspective of a political Event, legal, and illegal (i.e., armed) forms of struggle complement each other: the former allows greater influence, flexibility, moral, and financial support, and greater space for critique, while the latter provides autonomy. Sison's wisdom exactly explained this point: combination of legal and illegal forms of struggle. ${ }^{56}$

The possible deployment of violence within the parameters set by an emancipatory politics restricts violence itself. When Arendt raised the element of arbitrariness of violent political sequences, emphasizing the danger that "men's actions are beyond the actors' control," and that "[ $t]$ here is no certainty in these matters, not even an ultimate certainty of mutual destruction ..." 57 Arendt fell into what San Juan called as "an absolutist India," 127.

53 Gopal, “Concerning Maoism: Fanon, Revolutionary Violence, and Postcolonial

${ }^{54}$ Badiou explained that an emancipatory politics confronts the difficulty of having to deal with an existence which is outside of the State yet prescribing something that concerns the inside of the State. See for example Badiou "Affirmative Dialectics: From Logic to Anthropology," 9.

55 Ibid., 9.

${ }^{56}$ Jose Maria Sison, "On the Combination of Legal and Illegal forms of Struggle," in For Democracy and Socialism Against Imperialist Globalization (Manila: Aklat ng Bayan, 2009), 3438.

${ }^{57}$ Arendt, On Violence, 4.

(c) 2016 Regletto Aldrich D. Imbong

http://www.kritike.org/journal/issue 19/imbong december2016.pdf

ISSN 1908-7330

(c) BY-NC-ND 
censure of violence bereft of intentionality ..." 58 Violence must be seen as a consequence of an initial affirmation. In this sense, violence in itself is not a creative act since only the Event is. But since the Event is pure affirmation (of the New), and since the Event itself must be affirmed (by political subjects), there needs a consequent negation, i.e., violence. ${ }^{59}$ This means that political violence, if it has to be deployed, must be within the construction, consolidation and defense of emancipatory politics' maxim: equality. In particular terms, since inequality is the condition of the State-Capital combine, political violence is and should only be aimed at this combine. This means that equality directs violence: the communist Idea must command the gun. ${ }^{60}$

Social Sciences Cluster, University of the Philippines Cebu, Philippines

\section{References}

Arendt, Hannah, On Violence (New York: Harcourt Brace Jovanovich, 1970). Badiou, Alain, "Affirmative Dialectics: from Logic to Anthropology," in The International Journal of Badiou Studies, 2:1 (2013).

Being and Event, trans. by Oliver Feltham (New York: Continuum, 2005).

Conditions, trans. by Steven Corcoran (New York: Continuum, 2008).

In Praise of Love, trans. by Peter Bush (Paris: Flammarion, 2012).

Logics of Worlds: Being and Event II, trans. by Alberto Toscano

(New York: Continuum, 2009).

Metapolitics, trans. by Jason Barker (New York: Verso, 2011).

Philosophy and the Event, trans. by Louise Burchill (Massachusetts:

Polity Press, 2013).

Philosophy for Militants, trans. by Bruno Bosteels (New York:

Verso, 2012).

Plato's Republic, trans. by Susan Spitzer (New York: Columbia University Press, 2012).

Chatterjee, Ronjaunee, "Alain Badiou in Southern California: A Politics of the Impossible," in Los Angeles Review of Books (6 February 2014), $<$ https://lareviewofbooks.org/article/alain-badiou-southerncalifornia-politics-impossible/\#!>, 5 December 2015.

\footnotetext{
58 San Juan, "Nationalism, the Postcolonial State, and Violence," 22.

${ }^{59}$ Badiou explains that "we do not start with the creativity of negation as such, even if the site of negativity is included in the consequences of something affirmative. See Badiou, "Affirmative Dialectics: From Logic to Anthropology," 4.

${ }^{60}$ Alain Badiou, Plato's Republic, 110.
}

(C) 2016 Regletto Aldrich D. Imbong http://www.kritike.org/journal/issue 19/imbong december2016.pdf ISSN 1908-7330 


\section{BADIOU AND VIOLENCE}

Constantino, Renato, The Philippines: A Past Revisited, vol. 1 (Quezon City: The Foundation for Nationalist Studies, 1975)

Guerrero, Amado, Philippine Society and Revolution (Manila: Aklat ng Bayan, 2006).

Gopal, Priyamvada, “Concerning Maoism: Fanon, Revolutionary Violence, and Postcolonial India," in The South Atlantic Quarterly, 112:1 (2013).

Lenin, Vladimir, V.I. Lenin: Collected Works, trans. by Stepan Apresyan and Jim Riordan (Moscow: Progress Publishers, 1917).

Locke, John, "The Second Treatise of Civil Government," in The Great Political Theories, vol. 1, ed. by Michael Curtis (New York: Harper Perennial Modern Classics, 2008).

Lucas, Vanessa and Azadeh Shahshahani, "The Philippine People Are Under Attack from Washington - and Their Own Government," in The World Post (3 December 2016), $<$ http://www.huffingtonpost.com/azadeh-shahshahani/thephilippine-people-are b 8714174.html >, 4 January 2016.

McGowan, Todd, "Subject of the Event, Subject of the Act: The Difference Between Badiou's and Žižek's Systems of Philosophy," in Subjectivity, 3:1 (2010), 21-22. vol. 3, no. 1 (2010): 21-22

Meillassoux, Quentin, "History and Event in Alain Badiou," trans. by Thomas Nail in Parrhesia, 12 (2011).

"New People's Army (NPA) launches a series of tactical offensive against Estrada's reactionary armed forces," in People's March: Voice of the Indian Revolution (September-October 1999), $<$ http://www.bannedthought.net/India/PeoplesMarch/PM19992006/archives/1999/sep-oct 99/npa.htm>, 22 December 2015.

Pagaduan-Araullo, Carol, "Lumad killings and counterinsurgency," in Bulatlat: Journalism for the People (21 September 2015), $<$ http://bulatlat.com/main/2015/09/21/lumad-killings-andcounterinsurgency/>, 22 December 2015.

Reyes, Alvaro, “On Fanon's Manichean Delirium," in The Black Scholar: Journal of Black Studies and Research, 42:3-4 (2012).

"Richest 1\% will own more than all the rest by 2016," in Oxfam International $(19$ January 2015),

$<$ https://www.oxfam.org/en/pressroom/pressreleases/2015-0119/richest-1-will-own-more-all-rest-2016>, 7 January 2016.

Rousseau, Jean-Jacques, Discourse on the Political Economy and the Social Contract, trans. by Christopher Betts (New York: Oxford University Press, 1994).

San Juan, Epifanio Jr., "Nationalism, the Postcolonial State, and Violence," in Pingkian: Journal for Emancipatory and Anti-Imperialist Education, 4:1 (2015). 
Sebastian, Raymond, "Lumads open 'identity museum' in Baclaran," in CBCP News (20 November 2015), $<$ http://www.cbcpnews.com/cbcpnews/?p=68121 $>, 22$ December 2015.

Sison, Jose Maria, "On the ceaseless state terrorism against the Filipino people since 1972," in International League of Peoples' Struggle (21 September 2015), <http://www.ilps.info/index.php/en/statements/1898-on-theceaseless-state-terrorism-against-the-filipino-people-since-1972>, 22 December 2015.

"On the Combination of Legal and Illegal forms of Struggle," in For Democracy and Socialism Against Imperialist Globalization (Manila: Aklat ng Bayan, 2009).

Suechting, Peter, "Global Capitalism with a Human Face?" in AC Voice (2 December 2012), <https://acvoice.com/2012/12/02/global-capitalismwith-a-human-face/>, 5 December 2015.

Tupaz, Voltaire, “\#Manilakbayan: UP Diliman welcomes 700 Lumad from Mindanao," in Rappler (26 October 2015), $<$ http://www.rappler.com/move-ph/110730-manilakbayan-updiliman-welcomes-lumad-mindanao >, 22 December 2015.

Vanzi, Sol Jose, "Bohol Cops in NPA Raid Fired, Charged for Neglect," in Philippine Headline News Online (13 June 1999),

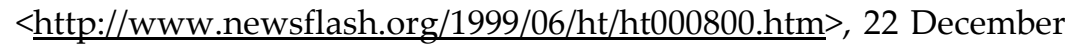
2015.

Weber, Max, The Vocation Lectures: Science as a Vocation, Politics as a Vocation, trans. by Rodney Livingstone, ed. by David Owen and Tracy Strong (Indianapolis: Hackett Publishing Company, 2004).

Žižek, Slavoj, Violence: Six Sideways Reflections (Pine Street: Profile Books, 2009). 